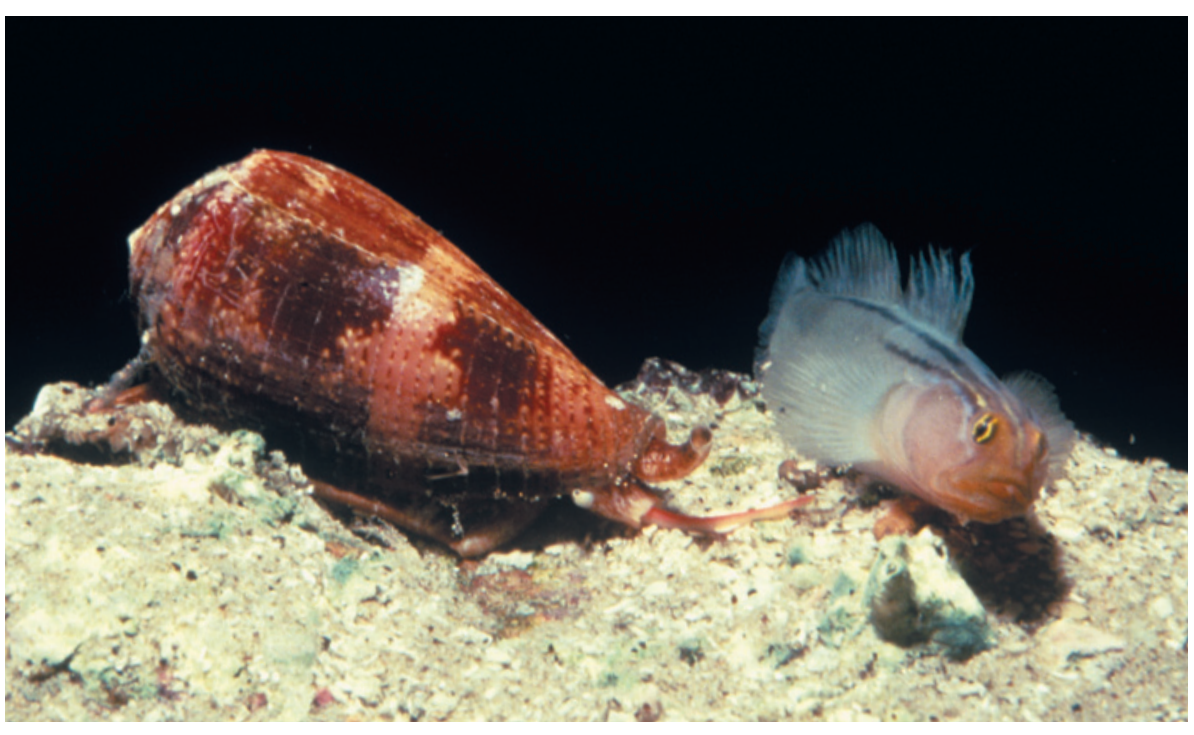

Drugs based on natural sources, such as sea-snail venom, are becoming harder to patent under US law.

\title{
POLICY
}

\section{Biotech reels over patent ruling}

Firms fight for right to patent natural products and processes.

\section{BY ERIKA CHECK HAYDEN}

$\mathrm{G}$ uidelines that forbid patents on a wide array of natural products, phenomena and principles have many in the biotechnology and pharmaceutical industries worried about the future of their business.

The rules, issued by the US Patent and Trademark Office in March, are open to public comment until 31 July and are reactions to two recent decisions by the US Supreme Court. In March 2012, the court ruled against Prometheus Laboratories in San Diego, California, saying that the company could not patent metabolite levels used to guide drug dosing. Then, in June 2013, the court rejected a patent claim by Myriad Genetics of Salt Lake City, Utah, on DNA sequences linked to breast cancer, opening the door for firms to develop genetic tests of breast-cancer risk. In both cases, the court based its decision on a section of patent code that forbids patenting "laws of nature, natural phenomena and abstract ideas". The guidance now states that patentable inventions must be "significantly different" from any natural product.

The patent office has decided that because the decisions in these cases built on previous rulings that involved a wide range of natural phenomena and products, the policy should apply to all claims reciting or involving such laws of nature.

But critics say that many existing medicines would not have qualified for protection under this standard - and that deserving patents are now being rejected. "Not having patents means not having drugs," says Kevin Noonan, a patent lawyer at McDonnell Boehnen Hulbert \& Berghoff in Chicago, Illinois.

Sherry Knowles, a legal consultant in Atlanta, Georgia, and former chief patent counsel at the drug company GlaxoSmithKline, estimates that almost half the drugs approved in the United States from 1981 to 2010 would have been rejected under these guidelines because they were natural, derived from nature, consisted of biological molecules such as antibodies or were vaccines, which often contain natural ingredients such as pieces of genes or proteins.

Knowles and others argue that the Myriad ruling struck down patents only on DNA that has been isolated from nature, and that the patent office's policy overreaches in covering too many nature-based products and processes. For instance, the guidance instructs patent examiners that a recipe for keeping fruit juice fresh by mixing it with vitamin $\mathrm{E}$ might not be patentable because neither the juice nor the preservative have been significantly modified from their natural form. "In the court's decisions, 'natural products' is not limited to DNA," explains June Cohan, a legal adviser to the patent office.

Patent seekers seem to have been affected by the precedents even before the guidelines were released. A survey released on 25 June by publisher Bloomberg BNA in Bethesda, Maryland, found that the patent office had denied $40 \%$ of the 1,000 or so applications that fall into areas covered by the guidance and filed since April 2011 - most of which were reviewed after the Prometheus ruling. Patents were rejected for instance, for proteins intended for diagnosis, medicines extracted from marine organisms and a test for detecting certain genetic traits in aquacultured fish.

That worries lawyers such as Hans Sauer, deputy general counsel for intellectual property at the Biotechnology Industry Organization, a trade group in Washington DC. "It's pretty clear that the Supreme Court intended the Myriad opinion to be a relatively specific and incremental one," he says. "Is it really the right outcome - that we're striking down patent applications on industrial enzymes going into laundry detergent, or on antibiotics?"

But others say that the government is acting exactly as it should. "It is doing the right thing for science, medicine and patients," says Roger Klein, a physician at the Cleveland Clinic in Ohio and chairman of the professional-relations committee for the Association for Molecular Pathology in Bethesda, one of the plaintiffs in the Myriad lawsuit.

The patent office does not have to amend its policy in response to public input, says spokesman Patrick Ross. But it will probably do so, he adds. "We're already reviewing the comments and looking to see what changes we might make." There is no set timeline for any changes.

The survey notes that many companies have been able to overcome patent rejections by making it clear to examiners that their invention differs significantly from something found in nature. For instance, the aquaculture application succeeded once it showed how the applicant had used genetic information to breed cod that are more suitable for farming.

"Companies are waiting and trying to see what they could do to avoid a problem," says Matthew McFarlane, a patent lawyer at Robins, Kaplan, Miller \& Ciresi in New York City, who co-authored the survey. "This is the way it always happens when the rules change." -

\section{CORRECTIONS}

The third reference cited in the News story 'Risks of flu work underrated' (Nature 511, 13-14; 2014) was incorrect. It should have read: Herfst, S. et al. Science 336, 15341541 (2012). In the Editorial 'Biosafety in the balance' (Nature 510, 443; 2014), a typographical error meant that the wrong year was given for the 11 September attacks - they happened in 2001. And the News Feature 'Close collaborators' (Nature 510, 458-460; 2014) accidentally described IBM's research site in San Jose, California, as the headquarters. 